\title{
Efek samping terapi steroid intravena pada penderita infeksi susunan saraf pusat di Departemen Neurologi RSUP Prof. Dr. R. D. Kandou Manado periode Juli 2014 - Juni 2015
}

\author{
${ }^{1}$ Ezra L. P. Sumampouw \\ ${ }^{2}$ Arthur H. P. Mawuntu \\ ${ }^{2}$ Rizal Tumewah
}

\author{
${ }^{1}$ Kandidat Skripsi Fakultas Kedokteran Universitas Sam Ratulangi Manado \\ ${ }^{2}$ Bagian Ilmu Neurologi Fakultas Kedokteran Universitas Sam Ratulangi Manado \\ Email: sumampouwezra@ rocketmail.com
}

\begin{abstract}
Intravenous steroid is a therapeutic option for patients with central nervous system infection to reduce severe inflammation in brain and spinal cord. Albeit, excessive dose and overload duration intravenous steroid can cause variety side effects to the patients from the mildest to the worst, such as headache, gastrointestinal disturbance, or a new kind of infection that may result from intravenous steroid therapy. This was a retrospective cohort study using medical records of patients with central nervous system infection in Prof. R. D. Kandou Manado Hospital period July 2014 to June 2015. There were 22 patients in this study consisted of 16 males and 6 females. Intravenous steroid dexamethasone was the most common steroid administered to 19 patients, followed by methylprednisolone to 3 patients. Mild side effects were found in 72.3 patients and the most common one was mild headache. Conclusion: Intravenous steroids were safe enough as an adjunctive therapy in patients with central nervous system infections in Prof. Dr. R. D. Kandou Hospital Manado.
\end{abstract}

Keywords: central nervous system infection, intravenous steroids, side effects

\begin{abstract}
Abstrak: Steroid intravena merupakan terapi pilihan untuk penderita infeksi susunan saraf pusat yang berfungsi mengurangi peradangan pada otak dan sumsum tulang belakang. Pemberian steroid intravena dengan dosis dan durasi yang berlebihan dapat menimbulkan efek samping yang beragam pada penerima terapinya mulai dari ringan hingga yang terberat, seperti nyeri kepala, gangguan gastrointestinal, hingga jenis infeksi baru yang dapat ditimbulkan akibat steroid intravena. Jenis penelitian ialah studi kohort retrospektif berdasarkan data rekam medik pasien dengan infeksi susunan saraf pusat yang dirawat di RSUP Prof. Dr. R. D. Kandou Manado periode Juli 2014 sampai Juni 2015. Terdapat 22 pasien dalam studi ini terdiri dari 16 laki-laki dan 6 perempuan. Jenis steroid intravena deksametason yang terbanyak diberikan pada 19 pasien, disusul metilprednisolon yang diberikan pada 3 pasien. Efek samping ringan ditemukan pada 72,3 kasus dan yang terbanyak ialah nyeri kepala ringan. Simpulan: Steroid intravena cukup aman diberikan sebagai terapi tambahan untuk penyakit infeksi susunan saraf pusat di RSUP Prof. Dr. R. D. Kandou Manado.
\end{abstract}

Kata kunci: infeksi susunan saraf pusat, steroid intravena, efek samping

Infeksi susunan saraf pusat (SSP) menyebabkan peradangan hebat pada otak dan medula spinalis yang dapat memperburuk keadaan pasien dan berpengaruh pada mortalitas dari tiap kasus yang terjadi. Insidens infeksi SSP seperti meningitis bakteri berada di kisaran 2,6 dan 6 per 100.000 orang dewasa tiap tahunnya di negara-negara maju, dan mungkin meningkat 10 kali di beberapa daerah 
negara-negara berkembang. ${ }^{1-3}$ Studi terbaru menunjukkan bahwa tingkat kematian pada meningitis bakteri ialah $13-27 \%$, bahkan pada saat terapi antibiotik sudah diberikan, banyak penderita yang sembuh dengan cacat neurologik. ${ }^{1}$ Penyakit infeksi lainnya yaitu ensefalitis yang disebabkan oleh Herpes Simplex Virus (HSV) dapat menyebabkan necrotizing yang parah (jika tidak ditangani menyebabkan kematian pada $70 \%$ kasus) hingga sedang yang berakibat cacat berat pada sebagian besar penderita. ${ }^{4}$ Keadaan penderita infeksi susunan saraf pusat yang memburuk ini membuat steroid intravena menjadi pilihan untuk terapi tambahan pada kasus-kasus tersebut. ${ }^{5-7}$

Steroid sudah digunakan sejak tahun 50-an sebagai obat anti-inflamasi dan imunosupresif. ${ }^{5}$ Pada beberapa kasus seperti meningitis tuberkulosis pada orang dewasa non-HIV atau meningitis bakterial akut, pemberian steroid intravena dapat memperbaiki keadaan penderita. ${ }^{6,7}$ Deksametason merupakan jenis steroid intravena yang banyak digunakan sebagai terapi pendamping pada pengobatan penyakit infeksi karena diketahui memiliki penetrasi yang baik pada susunan saraf pusat dan sifat anti-inflamasinya sudah diteliti dengan baik, ${ }^{7}$ walaupun demikian, pemberian steroid intravena dosis berlebihan dengan durasi yang lama dapat mengakibatkan efek samping. Terapi steroid menimbulkan efek anti-inflamasi dengan menekan aktivitas sistem kekebalan tubuh. Hal ini mengakibatkan individu penggunanya juga menjadi lebih rentan terhadap infeksi. Obat-obat steroid sendiri memiliki efek samping yang bervariasi dari ringan sampai berat, yang cukup sering diantaranya hiperglikemia, osteoporosis, dan hipertensi. ${ }^{8}$

Hingga saat ini belum ada data tentang kejadian efek samping dari terapi steroid intravena dan faktor-faktor yang memengaruhinya. Penelitian ini bertujuan untuk mendapatkan efek samping terapi steroid pada pasien infeksi susunan saraf pusat di RSUP Prof. Dr. R. D. Kandou Manado.

\section{METODE PENELITIAN}

Jenis penelitian ini ialah studi kohort retrospektif. Penelitian dilakukan di Departemen Neurologi Rumah Sakit Umum Prof. Dr. R. D. Kandou Manado dan sampel penelitian diambil dari data sekunder yaitu data rekam medik pasien infeksi susunan saraf pusat periode Juli 2014-Juni 2015. Sampel penelitian ialah semua populasi yang memenuhi kriteria penelitian inklusi dan eksklusi.

Yang termasuk kriteria inklusi ialah pasien infeksi susunan saraf pusat rawat inap, mendapat terapi steroid intravena, dan usia $>12$ tahun. Kriteria eksklusi ialah pernah mendapat terapi steroid $<7$ hari sebelum masuk rumah sakit; jenis, durasi, dan dosis steroid intravena tidak tercatat dalam rekam medik; ada riwayat hipertensi, diabetes mellitus, osteoporosis, gastritis, dan nyeri kepala primer sebelum masuk rumah sakit; dan pernah atau sedang menerima terapi obat-obat sitostatik, antiinflamasi non-steroid, atau modifying antirheumatoid drugs.

\section{HASIL PENELITIAN}

Dari penelitian ini didapatkan jumlah pasien infeksi SSP yang dirawat inap di Bagian Neurologi RSUP Prof. Dr. R. D. Kandou Manado dalam periode Juli 2014 Juni 2015 sebanyak 109 pasien tetapi hanya 22 kasus yang memenuhi kriteria penelitian. Pasien terbanyak ialah laki-laki $(81,2 \%)$ dan kelompok usia terbanyak ialah usia 13-49 tahun dengan rerata usia $40,3 \pm 16,5$ tahun. Sebagian besar pasien berpendidikan $<9$ tahun. Rata-rata pasien dirawat lebih dari dua minggu (Tabel 1).

Demam cukup mendominasi temuan klinis non-efek samping yang didapat pada pasien penderita infeksi SSP $(63,6 \%)$. Pada penelitian ini, gambaran klinis demam berhubungan secara bermakna dengan indikasi pemberian deksametason. Nilai tengah GCS ialah 13 (rentang 12). Hanya satu pasien positif HIV dalam penelitian ini sehingga sulit dinilai. Rerata leukosit pasien dalam penelitian meningkat dibanding normal (12.160,1 $\mathrm{sel} / \mathrm{mm}^{3}$ $\pm 5.061,7)$ (Tabel 1). Meningoensefalitis 
nonspesifik menjadi diagnosis utama terbanyak $(31,8 \%)$ dan ditemukan satu kasus mielitis (4,5\%). Sebanyak lima pasien $(22,7 \%)$ pasien dalam penelitian ini meninggal (Tabel 2).

Tabel 3 memperlihatkan sebaran karakteristik pasien menurut gambaran klinis non-efek samping

Tabel 1. Sebaran karakteristik sosiodemografik, klinis, dan laboratorik

\begin{tabular}{lccc}
\hline \multirow{2}{*}{ Karakteristik } & \multicolumn{2}{c}{ Nilai } & \multirow{2}{*}{$\boldsymbol{P}$} \\
\cline { 2 - 3 } & Rerata \pm 2SD & $\begin{array}{c}\text { Nilai Tengah } \\
\text { (Rentang) }\end{array}$ & \\
\hline Sosiodemografik & & &, 451 \\
Usia & $40,3 \pm 16,5$ & $43,0(54)$ &, 140 \\
Klinis & $15,45 \pm 10,8$ & &, 001 \\
Lama perawatan & $12,4 \pm 3,2$ & $14,5(40)$ &, 547 \\
$\begin{array}{l}\text { Skala koma Glasgow } \\
\text { Laboratorik }\end{array}$ & $13,5 \pm 2,7$ & $13,0(12)$ &, 993 \\
$\begin{array}{l}\text { Hemoglobin awal } \\
\text { Leukosit awal }\end{array}$ & $12.160,1 \pm 5.061,7$ & $11.680,0(21.900)$ &, 668 \\
Trombosit awal & $290.000 \pm 151.700$ & $274.000(586.000)$ &, 037 \\
$\begin{array}{l}\text { Natrium awal } \\
\text { Glukosa darah awal }\end{array}$ & $133,5 \pm 7,5$ & $134,5(37,0)$ &, 000 \\
$\begin{array}{l}\text { Glukosa darah } \\
\text { perawatan dalam }\end{array}$ & $124,2 \pm 43,2$ & $108,5(186)$ &, 000 \\
\hline
\end{tabular}

Tabel 2. Sebaran karakteristik sosiodemografik, klinis, diagnosis, dan luaran

\begin{tabular}{|c|c|c|c|}
\hline \multicolumn{2}{|l|}{ Karakteristik } & (n) & $(\%)$ \\
\hline \multicolumn{4}{|l|}{ Sosiodemografik } \\
\hline \multirow[t]{3}{*}{ Usia } & $12-30$ tahun & 7 & 31,8 \\
\hline & $31-49$ tahun & 9 & 40,9 \\
\hline & $\geq 50$ tahun & 6 & 27,3 \\
\hline \multirow[t]{2}{*}{ Jenis kelamin } & Laki-laki & 16 & 72,7 \\
\hline & Perempuan & 6 & 27,3 \\
\hline \multirow[t]{2}{*}{ Pendidikan } & $<9$ tahun & 3 & 13,64 \\
\hline & $\geq 9$ tahun & 19 & 86,36 \\
\hline \multicolumn{4}{|l|}{ Klinis } \\
\hline \multirow{2}{*}{ Status HIV } & Positif & 1 & 4,5 \\
\hline & Negatif & 21 & 95,5 \\
\hline \multirow[t]{2}{*}{ Demam } & Ya & 14 & 63,6 \\
\hline & Tidak & 8 & 36,4 \\
\hline \multirow[t]{2}{*}{ TRM } & Positif & 5 & 22,7 \\
\hline & Negatif & 17 & 77,3 \\
\hline \multirow[t]{7}{*}{ Diagnosis utama } & Meningitis tuberkulosis & 2 & 9,1 \\
\hline & Meningitis bacterial & 2 & 9,1 \\
\hline & Abses serebri & 6 & 27,3 \\
\hline & Ensefalitis viral & 3 & 13,6 \\
\hline & Ensefalitis toksoplasma & 1 & 4,5 \\
\hline & Meningoensefalitis non-spesifik & 7 & 31,8 \\
\hline & Mielitis & 1 & 4,5 \\
\hline \multirow[t]{2}{*}{ Luaran } & Hidup & 17 & 77,3 \\
\hline & Mati & 5 & 22,7 \\
\hline
\end{tabular}


Sumampouw, Mawuntu, Tumewah: Efek samping terapi steroid ...

Tabel 3. Sebaran karakteristik pasien menurut gambaran klinis non-efek samping

\begin{tabular}{|c|c|c|c|c|c|c|c|}
\hline \multirow{3}{*}{ Variabel } & \multicolumn{6}{|c|}{ Jenis steroid } & \multirow{3}{*}{$\begin{array}{c}\text { Nilai } \\
\mathbf{P}\end{array}$} \\
\hline & \multicolumn{2}{|c|}{ Deksametason } & \multicolumn{2}{|c|}{ Metilprednisolon } & \multicolumn{2}{|c|}{ Total } & \\
\hline & $\mathrm{n}$ & $\%$ & $\mathrm{n}$ & $\%$ & $\mathrm{n}$ & $\%$ & \\
\hline \multicolumn{8}{|l|}{ Penurunan } \\
\hline kesadaran & 9 & $40,91 \%$ & 2 & $9,09 \%$ & 11 & $50,00 \%$ & 0,53 \\
\hline Demam & 14 & $63,64 \%$ & 0 & $0,00 \%$ & 14 & $63,64 \%$ & 0,01 \\
\hline Kaku kuduk & 4 & $18,18 \%$ & 1 & $4,55 \%$ & 5 & $22,73 \%$ & 0,64 \\
\hline
\end{tabular}

Normalitas distribusi seluruh variabel penelitian numerik diuji dengan uji Shapiro-Wilk karena sampel kurang dari 50. Didapatkan data yang terdistribusi normal ialah usia, lama perawatan, hemoglobin awal, leukosit awal, dan trombosit awal sedangkan skala koma Glasgow, natrium awal, glukosa darah awal, dan glukosa darah dalam perawatan tidak terdistribusi normal (Tabel 4).

Tabel 4. Analisis normalitas variabel numerik

\begin{tabular}{lc}
\hline Karakteristik & P \\
\hline Usia & 0,45 \\
Lama Perawatan & 0,14 \\
Skala koma Glasgow & 0,00 \\
Hemoglobin awal & 0,55 \\
Leukosit awal & 0,99 \\
Trombosit awal & 0,67 \\
Natrium awal & 0,04 \\
Glukosa darah awal & 0,00 \\
Glukosa darah dalam perawatan & 0,00 \\
\hline
\end{tabular}

Data hasil pemeriksaan laboratorium tidak dapat diperoleh secara lengkap untuk semua kasus. Hal ini kemungkinan disebabkan oleh data yang hilang, tidak ada pemeriksaan laboratorium untuk pasien, keterbatasan biaya, dan indikasi.

Rerata leukosit pada pasien yang sudah diterapi steroid intravena mengalami penurunan tetapi masih di atas definisi leukopenia yang digunakan dalam penelitian ini $\left(12.160 / \mathrm{mm}^{3}\right)$. Demikian juga rerata hemoglobin mengalami penurunan tetapi masih dalam batas normal $(12,8 \mathrm{~g} / \mathrm{dl})$ dan diikuti oleh rerata trombosit $\left(285.000 / \mathrm{mm}^{3}\right), \quad$ Natrium serum $(137,8$ meq/l), dan glukosa darah sewaktu (133,2 $\mathrm{mg} / \mathrm{dl}$ ) yang masih dalam batas normal. Rerata hemoglobin awal, natrium serum awal, dan glukosa darah sewaktu awal mengalami perubahan yang bermakna secara statistik dengan nilainya setelah mendapat terapi steroid intravena $(p=0,01$; $\mathrm{p}=0,01$; dan $\mathrm{p}=0,05)$ sedangkan rerata leukosit dan trombosit tidak bermakna $(\mathrm{p}=0,071 ; \mathrm{p}=0,75)$.

Jenis steroid intravena yang ditemukan pada penelitian ini hanya deksametason $(86,3 \%)$ dan metilprednisolon untuk terapi kasus mielitis. Terdapat satu kasus $(4,5 \%)$ yang mendapat terapi keduanya. Efek samping ditemukan pada 16 pasien yang semuanya berupa efek samping ringan. Hiperglikemia (glukosa darah sewaktu $>200 \mathrm{mg} / \mathrm{dl}$ ) ditemukan pada 2 pasien. Efek samping pada deksametason ditemukan pada $68,2 \%$ dari 19 pasien yang mendapatkan deksametason. Metiprednisolon diberikan pada 3 pasien dengan presentase efek samping 4,5\% (Tabel 5).

Oleh karena tidak ditemukan efek samping berat maka hubungan yang diperiksa ialah antara karakteristik subjek dengan ada tidaknya efek samping dan bukan terhadap berat ringannya efek samping. Selain itu, tidak semua efek samping ditemukan dalam penelitian ini sehingga tidak dapat dilakukan uji statistik.

Variabel luaran secara statistik memiliki hubungan yang bermakna dengan timbulnya efek samping. Pada analisis multivariat dengan metode regresi linear terhadap variabel kategorik dengan nilai $\mathrm{p} \leq 0,25$ yaitu pendidikan, tanda rangsangan meningeal, jenis steroid, dan luaran dengan timbulnya efek samping ditemukan variabel luaran memiliki hubungan yang 
bermakna secara statistik dengan timbulnya efek samping ( $\mathrm{p}=0,023$; IK95\% 0,08 0,97) (Tabel 6).

Hasil uji statisik hubungan antara jenis efek samping dan luaran diperlihatkan pada Tabel 7. Terlihat bahwa hanya nyeri kepala yang secara bermakna berhubungan dengan luaran yang buruk. Analisis statistik untuk mencari hubungan antara beratnya efek samping, jenis efek samping, dan luaran dengan jenis steroid tidak mendapatkan hubungan yang bermakna.

Nilai hemoglobin awal dan skala koma Glasgow memiliki hubungan yang bermakna secara statistik dengan timbulnya efek samping ( $\mathrm{p}=0,00$ dan 0,02 masingmasing) (Tabel 8).

Tabel 5. Sebaran karakteristik steroid intravena dan temuan efek samping

\begin{tabular}{lccc}
\hline \multirow{2}{*}{ Jenis steroid } & \multicolumn{2}{c}{ Efek samping } & \multirow{2}{*}{ Total } \\
\cline { 2 - 3 } & $\begin{array}{c}\text { Ada } \\
(\mathrm{n}, \%)\end{array}$ & $\begin{array}{c}\text { Tidak ada } \\
(\mathrm{n}, \%)\end{array}$ & \\
\hline Deksametason & $15(68,2 \%)$ & $4(18,2 \%)$ & $19(86,45 \%)$ \\
\hline Metilprednisolon & $1(4,5 \%)$ & $2(9,1 \%)$ & $3(13,6 \%)$ \\
\hline Total & 16 & 6 & $22(100 \%)$ \\
\hline
\end{tabular}

Tabel 6. Hubungan karakteristik subjek dengan timbulnya efek samping

\begin{tabular}{lc}
\hline Karakteristik & P \\
\hline $\begin{array}{l}\text { Sosiodemografik } \\
\text { Jenis kelamin }\end{array}$ & \\
Laki-laki & 0,28 \\
Perempuan & \\
\hline $\begin{array}{l}\text { Pendidikan } \\
<9 \text { tahun } \\
9 \text { tahun }\end{array}$ & 0,25 \\
\hline Klinis & \\
Status HIV & \\
Positif & 0,53 \\
Negatif & \\
\hline Demam & 1,00 \\
Ya & \\
Tidak & \\
\hline Tanda rangsangan meningeal & 0,06 \\
Ya & \\
\hline Tidak & \\
\hline Diagnosis & 0,45 \\
Beningitis tuberkulosis & 0,01 \\
\hline Jenis steroid & \\
Deksametason & \\
Metilprednisolon & \\
\hline Luaran & \\
Hidup & \\
\hline
\end{tabular}


Tabel 7. Hubungan jenis efek samping dengan luaran

\begin{tabular}{lc}
\hline Jenis efek samping & P \\
\hline Nyeri kepala ringan & \\
Ada & 0,00 \\
Tidak & \\
\hline $\begin{array}{l}\text { Kelemahan otot tanpa } \\
\text { mobilitas }\end{array}$ & 1,00 \\
Ada & \\
Tidak & \\
\hline Hiperglikemia tanpa penyulit & 1,00 \\
Ada & \\
Tidak & \\
\hline Nyeri ulu hati & 1,00 \\
Ada & \\
Tidak & \\
\hline
\end{tabular}

Tabel 8. Hubungan karakteristik subjek dengan timbulnya efek samping

\begin{tabular}{lccc}
\hline Karakteristik & P & \multicolumn{2}{c}{ IK 95\% } \\
\cline { 3 - 4 } & & Batas bawah & Batas atas \\
\hline Usia & & $-20,53$ & 13,03 \\
Lama Perawatan & 0,65 & $-11,79$ & 10,29 \\
Hemoglobin Awal & 0,89 & $1.715,21$ & $5.922,29$ \\
Leukosit Awal & 0,00 & $-4.298,60$ & $6.028,70$ \\
Platelet Awal & 0,73 & $-4.529,36$ & $10.487,69$ \\
Skala koma Glasgow & 0,07 & & \\
Natrium serum awal & 0,02 & & \\
Glukosa darah sewaktu awal & 0,44 & & \\
Glukosa darah sewaktu dalam perawatan & 0,46 & & \\
\hline
\end{tabular}

\section{BAHASAN}

Jumlah kasus infeksi SSP di RSUP Prof. Dr. R. D. Kandou meningkat cukup banyak dari paruh akhir tahun 2014 ke tahun paruh pertama tahun 2015. Dari data tahun sebelum 2014 memang didapatkan kecenderungan peningkatan kasus di awal tahun. Hal ini mungkin berhubungan dengan musim namun secara keseluruhan terdapat peningkatan kasus yang mungkin berhubungan dengan peningkatan kewaspadaan dokter di RSUP Prof. Dr. R. D. Kandou terhadap kasus-kasus infeksi SSP.

Kasus infeksi SSP pada AIDS memberikan kontribusi terbesar. Hal ini ditemukan juga di rumah-rumah sakit lain di Indonesia seperti di RSUP dr. Cipto Mangunkusumo Jakarta, RSUP Hasan Sadikin Bandung, dan RSUP dr. Soetomo Surabaya. Steroid tidak direkomendasikan untuk diberikan pada pasien AIDS dengan infeksi oportunistik otak sehingga tidak banyak informasi yang bisa diperoleh. ${ }^{9}$

Kasus infeksi susunan saraf pusat yang dapat dianalisis hanya 22 kasus $(20,2 \%)$. Hal ini disebabkan 74,3\% rekam medik tidak memiliki catatan yang lengkap untuk dianalisis. Keadaan ini juga ditemukan pada penelitian lain yang menggunakan rekam medik untuk mencari data penelitian. Meski demikian jumlah tersebut sudah cukup memenuhi kebutuhan sampel minimal. 
Rata-rata pasien dirawat lebih dari dua minggu. Hal ini masih sesuai dengan alur klinis rumah sakit. Pemberian steroid intravena perlu diberikan dalam dosis tinggi selama lebih dari satu minggu sehingga perlu dititrasi sebelum dihentikan atau diganti ke sediaan oral. Hal ini turut memengaruhi lama perawatan. Meningoensefalitis nonspesifik menjadi diagnosis utama terbanyak $(31,8 \%)$. Hal ini terjadi karena diagnosis etiologis tidak bisa ditegakkan. Pada kasus-kasus seperti ini umumnya para klinisi mengambil pendekatan empirik untuk pemberian antimikroba tetapi tidak semua kasus dapat diterapi empirik dengan tepat sehingga luarannya buruk.

Jenis steroid intravena yang ditemukan pada penelitian ini ialah deksametason dan metilprednisolon intravena. Steroid yang paling banyak digunakan ialah deksametason $(86,3 \%)$. Hal ini disebabkan karena kasus terbanyak ialah infeksi otak. Pada infeksi otak, jenis steroid yang dijadikan pilihan pertama di Bagian Neurologi RSUP Prof. Dr. R. D. Kandou Manado ialah deksametason. Hal ini juga ditemukan pada pusat-pusat kesehatan lain di seluruh dunia.

Efek samping ditemukan pada 16 pasien yang semuanya berupa efek samping ringan sedangkan efek samping berat tidak ditemukan. Hal ini mungkin disebabkan jumlah kasus hanya sedikit. Jenis efek samping yang paling banyak ditemukan ialah nyeri kepala ringan. Nyeri kepala ringan setelah pemberian steroid intravena dapat dijelaskan oleh beberapa hal. Gangguan kadar glukosa sepintas pada pemberian steroid dapat menyebabkan nyeri kepala. Efek withdrawal juga dapat menyebabkan nyeri kepala beberapa waktu setelah steroid mulai dikurangi atau dihentikan. Peningkatan tekanan darah sepintas juga mampu menyebabkan nyeri kepala. Penelitian ini tidak mencari secara spesifik kronologis nyeri kepala sehingga tidak dapat disusun dugaan penyebabnya.

Variabel luaran juga berhubungan secara bermakna dengan kejadian efek samping. Pada analisis multivariat, luaran juga menjadi variabel yang berhubungan secara bermakna dengan kejadian efek samping.

Adanya efek samping berhubungan luaran yang lebih buruk. Hal ini mungkin disebabkan oleh berbagai faktor. Penghentian steroid karena efek sampingnya tentu menghilangkan efek terapeutik steroid. Efek samping juga akan menyebabkan timbul masalah klinis baru pada pasien, mungkin menambah jenis terapi medikamentosis, mengurangi efikasi obat utama, atau memperlama lama rawat. Faktor-faktor tersebut akan memperburuk luaran.

Efek samping lain yang ditemukan dalam penelitian ini berupa kelemahan otot, hiperglikemia, dan nyeri ulu hati tidak berhubungan secara bermakan dengan luaran. Nyeri kepala mungkin menjadi tanda awal dari penyulit tekanan tinggi intrakranial yang dalam acuan pustaka disebutkan memperburuk prognosis. Belum dapat dijelaskan secara pasti mengenai hubungan antara nyeri kepala setelah pemberian steroid dengan luaran yang lebih buruk. Mungkin hal ini menjadi tanda bahwa efikasi steroid pada pasien tidak baik. Meskipun demikian, perlu diperiksa adanya nyeri kepala pada pasien yang diberikan steroid karena berhubungan dengan luaran yang lebih buruk.

Dalam penelitian ini, jenis steroid tidak memengaruhi beratnya efek samping. Jenis steroid juga tidak berhubungan dengan jenis efek samping maupun beratnya luaran. Walaupun demikian, hal tersebut perlu dikonfirmasi lagi karena hampir semua pasien menerima deksametason.

\section{SIMPULAN}

Dari hasil penelitian dan bahasan dapat disimpulkan bahwa:

1. Steroid intravena diberikan pada $20,2 \%$ kasus infeksi susunan saraf pusat yang dirawat inap di RSUP Prof. Dr. R. D. Kandou.

2. Efek samping ditemukan pada $72,3 \%$ kasus yang semuanya ringan. Efek samping utama yang ditemukan ialah nyeri kepala ringan.

3. Nyeri kepala yang timbul setelah 
pemberian steroid berhubungan dengan luaran yang lebih buruk.

4. Steroid intravena cukup aman diberikan sebagai terapi tambahan pada kasuskasus infeksi susunan saraf pusat.

\section{SARAN}

Untuk penelitian selanjutnya disarankan mengenai efek samping steroid jangka panjang dengan menggunakan lembar pemantauan sendiri. Juga diwaspadai keluhan nyeri kepala yang timbul setelah pemberian steroid jangka panjang.

\section{DAFTAR PUSTAKA}

1. van de Beek D, de Gans J, Spanjaard L, Weisfelt M, Reitsma JB, Vermeulen M. Clinical features and prognostic factors in adults with bacterial meningitis. $\mathrm{N}$ Engl $\mathrm{J}$ Med. 2004;351:1849-59.

2. Schuchat A, Robinson K, Wenger JD, Harrison LH, Farley M, Reingold AL, et al. Bacterial meningitis in the United States in 1995. Active Surveillance Team. N Engl J Med. 1997;337:970-6.

3. van de Beek D, de Gans J, Tunkel AR, Wijdicks EFM. Community- acquired bacterial meningitis in adults. N Engl J Med, 2006;354:4453.

4. Whitley RJ. Herpes simplex encephalitis: adolescents and adults. Antiviral Res. 2006;71:141-8.

5. Ciriaco M, Ventrice $\mathbf{P}$, Russo G, Scicchitano M, Mazzitello G, , Scicchitano F, et al. Corticosteroidrelated central nervous system side effects. J Pharmacol Pharmacother. 2013;S94-S98.

6. Farmakologi dan Terapi (5th ed). Depatemen Farmakologi dan Terapeutik Fakultas Kedokteran Universitas Indonesia, 2007; p. 496516

7. Fitch MT, van de Beek D. Drug inside: steroid in CNS infectious disease New indication for an old therapy. Nat Clin Pract Neurol. 2008; 4(2):97104.

8. Sitompul R. Kortikosteroid dalam tata laksana uveitis: Mekanisme kerja, Aplikasi klinis dan efek samping. J Indon Med Assoc. 2011;61(6):265-9.

9. Mawuntu AHP, Imran D, Prihartono J. Angka kematian pasien AIDS dengan infeksi oportunistik otak di RSCM. Neurona. 2011;28(3). 